\title{
ZALOŻENIA GEOPOLITYKI IWANA IV GROŹNEGO I JEJ REALIZACJA W ROSJI W LATACH 1547-1584. CZ. II
}

\begin{abstract}
W artykule przestawiono główne założenia geopolityczne w czasach rządów cara Rosji Iwana IV Groźnego i sposoby ich realizacji. Ekspansję Rosji w tym czasie ukierunkowała w dużym stopniu sama geografia, ale za konkretne działania w czasie i przestrzeni odpowiadał Iwan IV. Jeszcze w okresie Wielkiego Księstwa Moskiewskiego wytyczono główne zamierzenia geostrategiczne. Należały do nich: 1. Zapewnienie bezpieczeństwa od strony granic wschodnich państwa i skierowanie ekspansji przeciwko państwom będących spadkobiercami Mongołów. 2. Zdobycie dostępu do Bałtyku i przesunięcie granic na zachód, w celu zjednoczenia ziem należących na przestrzeni wieków do Rusi Kijowskiej. To „zbieranie ziem ruskich” miało też połączyć wyznawców prawosławia pod jednym panowaniem Cerkwi rosyjskiej. 3. Rozbudowa odpowiedniej ideologii dla uzasadnienia spraw politycznych. W tym czasie pojawia się teoria przedstawiająca Moskwę jako „trzeci Rzym”, mająca po upadku Konstantynopola potwierdzać władzę Moskwy nad wszystkimi ludami prawosławnymi, a w przyszłości także będąca czynnikiem uzasadniającym roszczenia rosyjskie do terenów po byłym Cesarstwie Bizantyńskim. Iwan IV Groźny w wyniku podjętych działań stał się jednym z pierwszych władców rosyjskich, który $\mathrm{z}$ dużymi sukcesami realizował te założenia geopolityczne, odnosząc przy tym również porażki. Był też pierwszym władcą, który dzięki swoim działaniom stworzył pojęcie „eurazjatyckiej Rosji”. Artykuł składa się z części omawiających realizację planów Iwana IV Groźnego oraz jego sukcesy i porażki w trzech głównych kierunkach jego polityki. Cele, jakie sobie wyznaczył car, nie zostały przez niego w pełni zrealizowane, ale odgrywały rolę uniwersalną także dla przyszłych władców Rosji, którzy jakby wypełniającjego testament polityczny, dążyli do podobnych celów w polityce zagranicznej. Osąd działań cara Iwana IV w Rosji do dziś nie jest jednoznaczny, oceny wahają sięod uwielbienia aż po nienawiść. Słowa kluczowe: Iwan IV Groźny, geopolityka, Rosja w XVI wieku, wojny rosyjskie.
\end{abstract}

\section{DZIALANIA IWANA GROŹNEGO DO POWSTANIA EURAZJATYCKIEGO IMPERIUM: KOLONIZACJA SYBERII, WOJNA O BALTYK, OPRICZNINA I IDEOLOGIA PAŃSTWOWA}

Otwarcie drogi przez Wołgę i Kamę na Syberię po podboju Kazania wyznaczyło nowe wyzwania dla Iwana IV. Za jego panowania zostały zapoczątkowane wyprawy na te tereny, połączone $\mathrm{z}$ rozszerzaniem kolonizacji rosyjskiej. Po sukcesach Iwana IV w Kazaniu, chan syberyjski Edygej uznał się wasalem cara, jednak w 1567 r. zwierzchnictwo to upadło. Na początku próby podboju Syberii podjęli oddolnie wielcy

${ }^{1}$ Mgr Krzysztof Surowiec, asystent w Zakładzie Nauk Humanistycznych, Wydział Zarządzania, Politechnika Rzeszowska, autor korespondencyjny: e-mail: ks@prz.edu.pl

${ }^{2}$ Prof. dr hab. Aleksander Razin, kierownik Katedry Etyki Moskiewskiego Państwowego Uniwersytetu im. M. Łomonosowa 
kupcy Stroganowowie i ich wynajęty Kozak doński, ataman Jermak. Paralela między Jermakiem a innymi odkrywcami i zdobywcami hiszpańskimi, portugalskimi, angielskimi czy holenderskimi jest dobrze widoczna. Można $z$ tego wywnioskować, że ówczesna Rosja, mimo swego dalekiego położenia, uczestniczyła w odkryciach tak jak inne państwa Zachodu, a w związku z tym nie była zacofana gospodarczo ani społecznie, aby takie wyprawy podjąć ${ }^{3}$. Aktywność bojarów i kupców na tym polu była symptomem zmian gospodarczych XVI w. Europie i tworzenia się nowych stref gospodarczych ${ }^{4}$.

Wyprawa podjęta przez Jermaka w 1581 r. zakończyła się pełnym sukcesem, w bitwie został pokonany chan Kuczum ${ }^{5}$, a jego państwo przestało istnieć. Jermak szybko wysłał poselstwo do Iwana IV z prośbą o posiłki i utrwalenie władzy nad nowymi obszarami Syberii. Stroganowowie dalej prowadzili kolonizację Syberii Zachodniej w imieniu cara, a przyspieszenie tego procesu nastapiło już po śmierci Iwana IV w roku $1584^{6}$. Zagrożenie buntami ludów syberyjskich wymusiło, że powstająca na tych terenach administracja rosyjskamusiała działać $\mathrm{w}$ duchu tolerancji. W wyniku tego postępowało wzmacnianie władzy wojska i wojewodów na nowo zdobytych terenach.

Podboje Iwana IV doprowadziły do powstawania państwa wieloetnicznego. Oprócz przeważającego żywiołu słowiańskiego coraz więcej przybywało innych ludów, co miało się jeszcze pogłębiać w przyszłości. W tym czasie zaczęły się tworzyć na terenie Rosji nowe siły społeczno-wojskowe, a mianowicie kozactwo. Zarządzanie Syberią sprawowane było przez prikaz kazański, zmiany nastąpiły dopiero w XVII w. ${ }^{7}$. Powoli w

${ }^{3}$ Jak pisze wybitny polski metodolog historii, Jerzy Topolski: „,w Rosji XVI w. da się stwierdzić zasadniczy, decydujący wpływ nowej szlachty na rządy, niezależnie od ich formy oraz współdziałania mniej czy bardziej skutecznego państwa w szlacheckich dążeniach ekonomicznych". Zob. szerzejJ. Topolski, Narodziny kapitalizmuw Europie w XIV-XVII w., Poznań 2003, s. 105. Siłą sprawczą tych zmian była - podobnie jak w całej Europie - tzw. nowa średnia szlachta. W Rosji byli to $d$ worianie, wykorzystywani między innymi przez Iwana IV do utrwalania samodzierżawia.

${ }^{4}$ Terminem „strefa gospodarcza” posługiwał się polski historyk Marian Małowist, który pod tym pojęciem rozumiał „makroregion charakteryzujący się dwoma podstawowymi cechami: podobną gospodarką i jednolitym charakterem jej związków z innymi strefami”. Zob. szerzej:M. Małowist, Wschód a Zachód Europy XIII-XVI wieku, Warszawa 2006, s. VII, 326-327.

${ }^{5} \mathrm{~W}$ bitwie $\mathrm{z}$ chanem Kuczumem ataman Jermak pokonał jego wojska w sile 30 tys., sam dysponując około 600-800 Kozaków dońskich. Przewaga techniczna i wyszkolenie jego armii zdecydowało o jego zwycięstwie. Por. H.Carrèred'Encausse, Eurazjatyckie imperium. Historia Imperium Rosyjskiego od 1552 r. do dzisiaj, Kęty 2014,s. 45-47. Z bardzo podobna sytuacja mamy do czynienia z czasie wyprawy Hermana Cortesa do Meksyku w latach 1519-1521 (por.A. Tarczyński, Podbój imperiów Inków i Azteków, Warszawa 2009, s. 86) i kampanii Roberta Clive'a w Bengalu w czasie bitwy pod Plassey w 1757 r. (por.G.B.Malleson, The Decisive Battles of India from 1746 to 1819, London 1885,s. 35-71).

${ }^{6}$ Według Fernanda Braudela Rosja ,wynalazła” Syberię. Jedynym pomostem z nią były drogi lądowe, które omijały niemal zupełnie Ural, rząd carski zakazał używania dawnego podbiegunowego szlaku morskiego użytkowanego przez Nowogród Wielki - obawiano się przemytu futer syberyjskich tą drogą. Stroganowowie otrzymali od Iwana IV Groźnego przywilej nadający im rozległe ziemie oraz prawo wprowadzania na teren Syberii rusznic. Od tej pory według francuskiego historyka podbój Syberii przebiegł dość szybko, bo około 100 tys. km² rocznie. Zob. szerzejF. Braudel, Kultura materialna, gospodarka i kapitalizm XV-XVIII wiek. Gry wymiany, t. III, Warszawa 1992, s. 412-427.

7 Następnie prikazposolski w okresie Smuty, a w czasie rządów cara Michała Romanowa utworzonoprikaz syberyjski. 
państwie Iwana Groźnego rozwijała się koncepcja, która będzie dominować aż do 1917 r., budująca model zarządzania częściami imperium rosyjskiego na zasadzie uwzględnienia ich specyfiki. Inaczej postępowała Anglia ze swoimi koloniami, budując model, gdzie obszary zamorskie stanowiły tylko części kolonialne całości ${ }^{8}$.

Zdobycie większej swobody działania na wschodnich granicach Rosji, wzmocnienie skarbu bogactwami $\mathrm{z}$ tamtych obszarów oraz zabezpieczenie bezpieczeństwa na wschodniej granicy państwa umożliwiły Iwanowi IV skupienie uwagi na kwestii dostępu do Bałtyku. Brak dostępu Rosjido tego morza powodował zamknięcie przed światem zewnętrznym. Walka o „Dominium Maris Baltici” rozpoczęła się właśnie w połowie XVI w. i miała trwać do XVIII w. Zmieniały się koalicje i następowali po sobie hegemoni, żadne państwo jednak nigdy nie osiągnęło zdecydowanej przewagi. Dla Rosji to okno na świat na stałe zdołał dopiero zdobyć traktatem z Nystad w 1721 Piotr Wielki, zdobywając tereny tzw. Inflant szwedzkich. W czasach Iwana IV te bogate tereny należały do słabnącego tworu, wywodzącego się jeszcze z okresu średniowiecza, mianowicie Zakonu Kawalerów Mieczowych. O spadek po tym państwie i o takie bogate miasta jak Tallin, Dorpat, Rygę, Narwę czy Mitawę rywalizowały Litwa i Polska (od 1569 r. Rzeczpospolita Obojga Narodów), Szwecja, Dania i Rosja. Do tych spraw mieszały się również Cesarstwo rządzone przez Habsburgów, Hanza i Anglia, nie mając jednak wiele do powiedzenia. Iwan IV i jego doradcy dostrzegli tę jedyną możliwość wzmocnienia państwa i uczynienia z niego bardziej znaczącego podmiotu w Europie poprzez zdobycie dostępu do Bałtyku. Gdyby to się udało, handel z Anglią i innymi krajami Zachodu zapewniłby nie tylko zyski ekonomiczne państwu, ale również dopływ nowoczesnej broni i specjalistów ${ }^{9}$. Na to w szczególności Rzeczpospolita, a także Szwecja nie mogły się w żaden sposób zgodzić ${ }^{10}$. Przyjazne stosunki z Danią natomiast nie przekreślały założeń Iwana IV na całkowity sukces. Bardzo ważnym czynnikiem geopolitycznym dla Iwana IV było również „zbieranie ziem ruskich”. Walka ta miała się rozstrzygnąć w wojnie z Litwą i Polską. Dawne tereny Rusi wchodzące w skład wspomnianych państw były znaczącym łupem nie tylko pod względem gospodarczym, religijnym, strategicznym, ale i ideologicznym.

Do pierwszego starcia z Zachodem doszło w okresie regencji Heleny Glińskiej, gdy Iwan IV był jeszcze małoletni. W latach 1534-1537 toczyła się wojna moskiewskopolska. Strona polska mimo zamieszania w państwie moskiewskim nie wykorzystała sytuacji, Rosjanie robili wypady w głąb Litwy, a druga strona próbowała zdobywać

\footnotetext{
${ }^{8}$ Model taki był realizowany przez angielski urząd: Colonial Office.

${ }^{9} \mathrm{~W}$ armii Iwana IV w związku z podbojami nastąpiła konieczność reformy wojska. Dotychczasowa jazda posiadaczy ziemskich pomiestia nie odgrywała już swojej roli. W związku z tym zostali powołani pod broń żołnierze kontraktowi, tzw. strzelcy, którzy byli muszkieterami. Według Carol Stevens kontraktowi żołnierze stanowili jedną trzecią całej armii. Strzelcy mieszkali w osobnych osiedlach, tzw. słobodach, i zajmowali się w czasach pokoju rzemiosłem, handlem i pełnili funkcje policyjne. Rozwijała się też rekrutacja żołnierzy cudzoziemskich, których Iwan IV miał utrzymywać już cztery tysiące. W 1577 r. utworzono prikaz strzelecki. Zob. szerzejC.B. Stevens, Rosyjskie wojny 1460-1730. Narodziny mocarstwa, Warszawa 2003, s. 90-102.

${ }^{10} \mathrm{~W}$ celu pogłębiania sojuszu ze Szwecją Katarzyna Jagiellonka, siostra Zygmunta Augusta II, wyszła za Jana III księcia Finlandii, ślub odbył się w 1562 r.
} 
Siewierszczyznę ${ }^{11}$. Ostatecznie w 1537 r. zdecydowano się na rozejm. Przy Litwie pozostał Homel,zdobyty wcześniej przez hetmana Stanisława Tarnowskiego.

Wojna toczona o Inflanty trwała długo,z kilkoma przerwami: od 1558 r. do 1583. Decyzję o wojnie wymusiły na Iwanie IV działaniaZakonu Kawalerów Mieczowych, którzy bliżej związali się z Litwą. Traktat pozwolski z 1557 r. mógł oznaczać, że Rosja nie uzyska nic w spadku po Zakonie, a główne korzyści uzyskają Polska i Litwa, ostatecznie odpychając Rosję od Bałtyku. Pierwszy okres wojny był bardzo korzystny dla cara $^{12}$. Zdobyto Narwę, Dorpat, Wenden, Fellin i wiele innych miast, dochodząc pod Rygę i Tallin. Te sukcesy Iwana IV zaniepokoiły inne kraje, a takżeHabsburgów ${ }^{13}$. Gdyarcybiskup ryski poddał się protektoratowi króla Polski Zygmunta II Augusta w 1559 r., przyspieszyło to decyzję innych państw o przystąpieniu do wojny. Książę Danii, Magnus, szybko zajął wyspę Ozylię, a Szwecja zajęła Estonię z Tallinem. Ostatni władca Zakonu, Gothard Ketller, postanowił w tej sytuacji uratować jak najwięcej dla siebie i wybrać najlepszego sojusznika, któryby zachował wolności szlachty inflanckiej. Wybór padł na króla Polski, w 1561 r. zawarto porozumienie oddające Inflanty w ręce Polski i Litwy, Kettler uzyskiwał rządy wasalne w księstwie Kurlandii i Semigalii, a Zakon został zsekularyzowany.

W ten sposób Iwanowi IV pełne zwycięstwo zaczęło wymykać się z rąk. Do tego doszły problemy wewnętrzne:śmierć pierwszej żony Iwana IV, Anastazji, i podejrzenia o jej otrucie przezgłównych doradców doprowadziły do zmian w kręgu faworytów cara $\mathrm{i}$ coraz bardziej przyczyniały się do zmian w jego charakterze. Te niepowodzenia i podejrzenia były główną przyczyną powstania opriczniny ${ }^{14}$. Zanim ona powstała, Iwan IV osiągnął duży sukces -jego wojska w 1563 r. zdobyły Połock ${ }^{15}$, który był silnie ufortyfikowanym miastem, broniącym dostępu do Wilna oraz stanowiącym klucz do żeglugi po Dźwinie. Od 1564 r. wojska rosyjskie coraz bardziej były w odwrocie, mimo zachowania Połocka Iwan IV tracił dotychczasowe zdobycze. W 1570 r. zawarł rozejm z

${ }^{11}$ Zob. szerzej:J. Natanson-Leski, Granica moskiewska w epoce jagiellońskiej, Oświęcim 2014, s. 144-153. W rokowaniach Iwan IV, mimoże miał 6 lat, występował oficjalnie jako osoba rozstrzygająca, choć faktycznie decydowała regentka Helena Owczyna-Oboleński i Wasyl Szujski.

${ }^{12}$ Według Williama Urbana car rozpoczął kampanię w 1558 r. z liczbą 64700 żołnierzy. Por.W. Urban, Nowożytni najemnicy, Warszawa 2008, s. 57. Dużym wsparciem dla Iwana IV okazał się dowódca najemników JürgenFarensbach, który odrzucił m.in. najazd tatarski znad Oki w 1572 r.

${ }^{13}$ Habsburgowie już wcześniej interesowali się sytuacją w Rosji, starając się szachować Polskę od wschodu w razie mieszania się jej w sprawy Mołdawii, Czech i Węgier oraz w razie sojuszu z Francją Walezjuszy. Ich dyplomata Siegmund von Herberstein (1486-1566), dwukrotnie pełnił funkcję posła w Moskwie: w 1517 r. i 1526. Jego dzieło Rerum MoscoviticarumCommentarii stanowi opis ówczesnego Wielkiego Księstwa Moskiewskiego. Habsburgowie byli rozczarowani tym, że Iwan IV skierował się na Zachód, a nie przeciwko Krymowi i Turcji.

${ }^{14}$ Opricznina była oddzielnym dworem i wojskiem, który Iwan IV powołał w $1565 \mathrm{r}$. w celu pozbycia się opozycji bojarskiej. Składała się z kilku tysięcy osób, które represjami umacniały pozycję władcy. Zlikwidowana w 1572 r. Por.L. Bazylow,P. Wieczorkiewicz, Historia Rosji, Wrocław 2005, s. 82-87;Z. Wójcik, Dzieje Rosji1533-1801, Warszawa 1971, s. 35-43. Według tego autora opricznina i wojna o Inflanty Iwana IV bardzo osłabiły Rosję i zostawiły ją nieprzygotowaną na przyszły kryzys dynastyczny i gospodarczy. Według Józefa Stalina opricznina to „królewskie wojsko..., nowoczesna armia".

${ }^{15}$ Natanson-Leski podaje liczbę wojsk moskiewskich na 200 tys. i 200 dział. Por.J. Natanson-Leski, op. cit., s.179. Według Skrynnikowa około 31 tys. wojska z artylerią. 
Rzeczpospolitą Obojga Narodów ${ }^{16}$, co dało trochę wytchnienia obu stronom, szczególnie Rosji coraz bardziej wyniszczanej działania miopriczniny. Iwan IV nadal snuł plany zdobycia tych terenów, a sposobność nadarzyła się już wkrótce. Śmierć ostatniego Jagiellona w 1572 r. i dłuższe bezkrólewie umożliwiły Iwanowi IV kontynuowanie walk w Inflantach. Czynniki polsko-litewskie w celu zapewnienia bezpieczeństwa państwa w trudnym okresie, obiecywały carowi wybór na tron polski. Nic z tego nie wyszło, jak również z planów rozbiorowych Iwana IV wobec Rzeczypospolitej skierowanych do cesarza Maksymiliana II $^{17}$. Do roku 1577 Iwan IV ponownie zajął prawie całe Inflanty z wyjątkiem Tallina i Rygi. Rok później do wojny przystąpiła Polska okazująca do tej pory pomoc drugiemu członowi unii czyli Wielkiemu Księstwu Litewskiemu. Rozpoczęła się nowa wojna o Liflandię i Estlandię. Ziszczenie się głównego celu geopolitycznego, czyli pełnego dostępu do Bałtyku, Iwanowi IV pokrzyżował nowy - od 1576 r. - król Polski, Stefan Batory, poprzednio książę siedmiogrodzki i zarazem wasal $\mathrm{z}$ tego terytorium Turcji ${ }^{18}$.

Stefan Batory razem ze Szwedami w latach 1577-1582 pozbawił państwo rosyjskie wszystkich dotychczasowych zdobyczy nad Bałtykiem. Zreformowana i powiększona armia Rzeczypospolitej w trzech głównych kampaniach pokonała Rosję. W 1579 r. udało się Polakom odbić Połock. Rok później zdobyto Wielkie Łuki, a także Newel, Wieliż i Uświat. W roku 1581 Batory próbował zdobyć Psków, ale nie udałomu się to. Wyczerpane państwa przystąpiły do negocjacji. Iwanowi IV udało się zdobyć poparcie przedstawiciela papieża jezuity Antonia Possevino ${ }^{19}$. W 1582 r. strony zawarły dziesięcioletni rozejm w Jamie Zapolskim, Rosja przekazała Polsce Inflanty, Połock oraz Wieliż z okolicami ${ }^{20}$. Rok później również Szwedzi zawarli z carem zawieszenie broni nad rzeką Plussą. Iwan IV musiał zrezygnować z Narwy, Jamu i Koporie.

Wojna na Zachodzie, mimo usilnych prób, zakończyła się klęską dla Iwana IV. Odsunęła w czasie modernizację Rosji i jej wejście do grona mocarstw europejskich. Potwierdziła również to, że Rosja jest jeszcze za słabo rozwinięta, aby walczyć z potęgami ówczesnego Zachodu. Klęska Iwana IV zahamowała ekspansję Rosji na Zachód na 100 lat. Mimo tej porażki car wiązał cały czas nadzieje na sojusz z Anglią Elżbiety I,

16 Rozejm zawarto do czerwca 1573 r. W skład poselstwa polskiego wchodzili wojewoda inowrocławski Jan Krotowski i kasztelan miński Mikołaj Talwosz. Przedstawili oni również Iwanowi IV w poufnej audiencji projekt wybrania go na króla Rzeczypospolitej w przyszłej elekcji.

${ }^{17} \mathrm{~W}$ sprawie szczegółów rosyjskiej polityki zagranicznej w okresie pierwszego (1572-1573) i drugiego (1574-1576) bezkrólewia w Rzeczypospolitej Obojga Narodów zob. szerzej:B.N. Floria, Russko-polskijeotnoszenii $i$ politiczeskojerazwitjeWostocznojJewropywowtoroj połowinie XVI naczale XVII w., Moskwa 1978, s. 46-120.

${ }^{18}$ Idem, Magnateria litewska a Rosja w czasie drugiego bezkrólewia,„Odrodzenie i reformacja”, 1977/XXII.

${ }^{19}$ O roli papieża i samego Posseviny w epoce Iwana IV zob.W. Zakrzewski, Stosunki Stolicy Apostolskiej z Iwanem Groźnym $i$ wielkim księciem moskiewskim, „Przegląd Polski” 1872-1873/I-IV.

${ }^{20}$ W rozejmie Possevino odmówił tytułowania Iwana IV carem bez zgody papieża. Zawarto kompromis, w którym Iwan IV pozostał przy tytule cara, ale jedynie w rosyjskiej wersji traktatu. Por. M. Khodarkovsky, Na granicach Rosji. Budowanie imperium na stepie 1500-1800, Warszawa 2009, s. 52. 
co nigdy się nie ziściło, choć takie próby były podejmowane już w 1570 r., a także zaraz przed śmiercią cara ${ }^{21}$.

Trzeci czynnik geopolityczny odgrywający dużą rolę w dziejach Rosji, mianowicie budowa tradycji imperialnej, opartej na idei Rosji jako „trzecim Rzymie” z roszczeniami wobec państw, gdzie mieszkali wyznawcy prawosławia i do terytoriów po byłym Cesarstwie Bizantyńskim, była kontynuowana przez Iwana IV. W budowie tej ideologii i wzmocnieniu pozycji władcy dużą rolę odgrywała Cerkiew prawosławna, ściśle podporządkowana władzy centralnej. Klęska unii kościołów uzgodnionej we Florencji w 1439 r. przyniosła wielkie korzyści władcom Rosji. Na tym etapie historycznym rosyjskość zrosła się z prawosławiem, carowie w tym względzie bardzo obawiali się ekspansji państw z Zachodu, ponieważ w przeciwieństwie do ekspansji Mongołów, byli oni zainteresowani w większości zmianą religii Rosjan, co wiązałoby się $\mathrm{z}$ upadkiem prawosławia. Powoli na terenach Wielkiego Księstwa Moskiewskiego, a później w Rosji kształtowała się kolejna ważna idea mająca wpływ na państwo i rządzących -tą ideą było dodanie określenia „święta” w nazwie państwa. „Święta Ruś” obejmowała nie tylko ziemię, naród, ale także państwo ${ }^{22}$.

Iwan IV, podobnie jak jego trzej poprzednicy, uważali Rosję za jedyny bastion prawdziwej wiary, która była dziedziczką Konstantynopola i miała dzięki temu misję dziejową do spełnienia. Ta ideologia rosyjskiej autokracji z biegiem lat stawała się coraz bardziej stabilna. Według niej każdy władca miał za zadanie rozszerzać granice prawosławnego królestwa, nie ponosząc przy tym odpowiedzialności przed ludźmi, lecz tylko przed Bogiem ${ }^{23}$. W związku z tym wystąpienie przeciw carowi było równoznaczne $\mathrm{z}$ buntem przeciw Bogu. Podobny legitymizm władzy wykształcił się międzyinnymi w Anglii Henryka VIII, jednak nie tak w skrajnej postaci jak w Rosji. Iwan IV używał religii do usprawiedliwienia swoich poczynań politycznych, często kończących się śmiercią tysięcy osób,tak jak w Nowogrodzie Wielkim ${ }^{24}$ w styczniu 1570 r. Z czasem Iwan IV

21 Car planował nawet zamieszkanie w Anglii w 1567 r. Por. M.Heller, Historia ImperiumRosyjskiego, Warszawa 2009, s. 168.

${ }^{22}$ Por.A. Besancon, Święta Ruś, Warszawa 2012, s. 37-39. Według autora prawosławie było zawsze czynnikiem spajającym społeczeństwo rosyjskie, przynajmniej do czasów socjalizmu. Zob. szerzej: A.V.Soloviev, Holy Russia. The History of a Religious - Social Idea, Gravenhage 1959. Niektórzy historycy, np. Gieorgij Wiernadski, przypisują Iwanowi IV „plan eurazjatycki”, który miał polegać na zdobyciu Kazania, Astrachania, Syberii, Krymu i otwarcia dzięki temu drogi na Kaukaz, Chiny i Morze Kaspijskie. Rezygnacja Iwana IV ze zdobycia Krymu była w związku z tym niesłuszna. Zob. szerzej: R. Bäcker, Międzywojenny eurazjatyzm. Od intelektualnej kontrakulturacji do totalitaryzmu?,Łódź 2000, s. 128-129.

${ }^{23}$ Według Jerzego Kłoczowskiego polityka Iwana IV, a w szczególności jego koronacja, oznaczała „zawarcie bliskiego sojuszu władców rosyjskich z potężnym monastycyzmem i programem monastycznej kultury religijnej obowiązującej cały naród". Tzw. sobór 100 rozdziałów w $1551 \mathrm{r}$. objął w ramy programu prawnego te założenia. Celem tego działania było stworzenie monolitycznej organizacji z prawosławnym carem - cesarzem na czele. Próbom tym towarzyszył przez cały czas przymus, a skutkiem realizacji tego programu było zahamowanie inicjatywy i dynamizmu życia religijnego. Zob. szerzejJ. Kłoczowski, Młodsza Europa, Warszawa 2003, s. 309-310.

${ }^{24}$ Dane o liczbie zabitych mieszkańców Nowogrodu są różne. Jak podaje Skrynnikow, miało zginą́ 2-3 tys. - por.R.G. Skrynnikow, TragiedijaNowgoroda, Moskwa 1994, s. 102-105. Według Kobrina miało to być aż od 10-15 tys. osób, por.W. Kobrin, Iwan Groznyj, Moskwa 1989, s. 81-83. 
kreuje siebie na kata i świętego, który osądza swoich poddanych. Można wtym zauważyć megalomanię ${ }^{25}$.

Ważnym symbolicznie i politycznie aktem dokonanym przez Iwana IV była jego koronacja na cara w styczniu 1547 r. Akcentowała ona kontynuację dziedzictwa Cesarstwa Bizantyńskiego. Szybko wykształciła się również odpowiednia terminologia rosyjska na określenie władcy: car, samodierżec - określenia te były odpowiednikami bizantyjskich tytułów: basileus czy autokrator ${ }^{26}$. Uzasadnienie przyjęcia tytułu cara wypływało, oprócz teorii o „trzecim Rzymie”, z przekazów o rządach księcia kijowskiego Włodzimierza Monomacha w XI w., który miał jakoby już wtedy otrzymać z Bizancjum tytuł cara. Koronację celebrował metropolita Makary za warunkową zgodą patriarchy Konstantynopola $^{27}$.

Już od połowy XVI w. Iwan IV zaczął tworzyć i przywiązywać dużą wagę do symbolicznego demonstrowania potęgi i chwały carskiej ${ }^{28}$. Ta propaganda miała za zadanie podnieść rolę Rosji na arenie międzynarodowej. Mimo oszałamiającego bogactwa Iwana IV, Rosja nadal była traktowana jako kraj peryferyjny. Jeszcze w pokoju westfalskim z 1648 r., kończącym wojnę trzydziestoletnią w Europie, Rosja była w nim wymieniona na przedostatnim miejscu w hierarchii ówczesnych krajów Europy. Ta sytuacja miała się diametralnie zmienić dopiero w okresie panowania Piotra Wielkiego. W okresie rządów Iwana IV mamy do czynienia w Rosji ze zjawiskiem sakralizacji władcy, które przejawiało się nie tyko w ideologii, ale również w obrzędowości.

${ }^{25}$ Szczególnie widać to w listach do bojara Andrzeja Kurbskiego, który uciekł do Polski, obawiając się śmierci z rąk cara, z którym Iwan IV prowadził szeroką korespondencję. Por.J.L.I. Fennell, The Correspondencebetween Prince A. M. Kurbsky and Tsar Ivan IV of Russia, Cambridge 1955; W. Kaługin, Car Iwan Groznyj i kniaź Andriej Kurbskij: Stili myszlenija i tworczestwa, [w:] Pisarz i władza. Od Awwakuma do Solzenicyna, Łódź 1994. Ingerencja w sprawy religijne ze strony Iwana IV była spora, mimo oficjalnego poparcia i wspierania Cerkwi w 1580 r. car zakazał jakichkolwiek darowizn na rzecz Cerkwi. Por.K. Krasowski, B.Lesiński,K. Sikorska-Dzięgielewska, J. Walachowicz, Powszechna historia państwa i prawa, Poznań 1993, s. 115-116.

${ }^{26}$ Oprócz Anglii tytułu carskiego nie uznawały żadne państwa w Europie zgodnie z zasadą wywodzącą się ze średniowiecza, że cesarz może być tylko jeden. Spór o tytuł carski nabrał ostrości, gdy poseł polski w Rzymie ks. Adam Konarski donosił, że Iwan IV za cenę przejścia na katolicyzm i poddanie się zwierzchności papieża zabiega o uznanie tytułu u papieża Juliusza III, mając poparcie zarówno Karola V i Ferdynanda, którzy rewanżowali się Polsce za jej kontakty z Francją. Por. Historia dyplomacji polskiej, t. I:Połowa X w. - 1572, red. M. Biskup, Warszawa 1982, s. 601 i 684. W XVI w. używany był czasem przez carów rosyjskich tytuł „Biały Car”, nawiązywał on pewnie do legendy „Białej Kości”, rodu Czyngis-chana i był swego rodzaju symbolem związków władców rosyjskich z mongolską dynastią panującą.

${ }^{27}$ Por.E. Acton, Rosja dziedzictwo caratu i władzy radzieckiej, Warszawa 2013, s. 33-34. Sobór z 1561 r. załączył do swoich uchwał list patriarchy Konstantynopola nazywajacego Iwana IV „cesarzem i seniorem prawosławnych chrześcijan na całym świecie”, co miało duże znaczenie propagandowe dla cara. Por.R. Pipes, Rosja carów, Warszawa 2012, s. 74.

${ }^{28}$ B.Uspienski, Car i patriarcha. Charyzmat władzy w Rosji. Bizantyjski model i jego nowe rosyjskie ujęcie, Katowice 1999. W przyszłości Uwarow stworzył fundamentalną triadę legitymizacyjną carat: prawosławie, samodzierżawie, ludowość. „Święty car” wiązał się naturalnie z „Swiętą Rusią”. Zob. szerzejP. Rojek, Przekleństwo imperium. Źródła rosyjskiego zachowania, Kraków 2014, s. $42-44$. 
Realizowaniu celów geopolitycznych służyły Iwanowi IV również reformy różnych dziedzin państwa, głównie w duchu antybojarskim i centralizacyjnym ${ }^{29}$. Wyrazem tych reform było nowy zbiór praw z 1550 r., zwany Sudiebnik ${ }^{30}$. Jeszcze większe znaczenie dla państwa miały reformy wojskowe, takie jak utworzenie nowej formacji - strzelców, wyposażonych w broń palną, powoływanie pod broń Kozaków czy jazdy tatarskiej z Kazania czy Astrachania. Kolejne zmiany w czasach Iwana IV nastąpiły w zakresiewładzy wykonawczej, w tym czasie wykształciły się prikazy jako urzędy administracji centralnej. Początkowo wydawało się, że Rosja Iwana IV zmierza w kierunku budowy monarchii stanowej, z przewagą władzy cara, jednak w latach sześćdziesiątych XVI w. zostało to przerwane. W wyniku konfliktu z bojarami i swoimi doradcami Iwan IV miał coraz większe trudności w rządzeniu państwem.To spowodowało, że znalazłwyjście $\mathrm{z}$ sytuacji i powołał nową instytucję opriczninę ${ }^{31}$. Jej działalność zadała wielki cios bojarom, ucierpiały również inne klasy społeczne. Dokonano niewyobrażalnych zniszczeń i rzezi ludności. Osłabione państwo padło ofiarą najazdu Tatarów krymskich, chana Dewlet-Gireja, który w 1571 r. dotarł do samej Moskwy, łupiąc ją i zabierając tysiące ludzi w jasyr. To uzmysłowiło carowi, że konieczne są zmiany. Opricznina została zlikwidowana w1572 r. Jej głównym osiągnięciem było zlikwidowanie konfliktu między carem a bojarstwem. W tym samym roku udało się rozbić drugi najazd Tatarów Dewlet-Gireja, co umocniło Rosję od południa i na długo zahamowało ekspansję tatarsko-turecką ${ }^{32}$.

Polityka wewnętrzna cara Iwana IV służyła więc realizacji polityki zewnętrznej i tak trzeba ją rozpatrywać. Sukcesy i porażki na arenie zewnętrznej były ściśle związane z polityką wewnętrzną. Od 1547 r. możnamówić o dużych sukcesach Iwana IV, po 1563 r. (kiedy zdobyto Połock) sytuacja państwa pogarszała się, co było wynikiem zamętu wewnętrznego wywołanego przez opriczninę. Sytuacja geopolityczna Rosji szczególnie na zachodnich granicach była słaba, a na arenie międzynarodowej Iwana IV był wyalienowany.

\section{PODSUMOWANIE}

Działania geopolityczne podejmowane przez Iwana IV w okresie jego rządów w latach 1547-1584 nie przyniosły samych sukcesów ówczesnej carskiej Rosji. Główne kierunki i koncepcje geopolityki wyznaczone były już przez poprzednich władców, choć rozmach ich realizacji należy do Iwana IV. Sukcesy w pierwszych dwóch dekadach rządów Iwana

${ }^{29}$ W.A.Serczyk, Radziecka dyskusja o absolutyzmie w Rosji, „Kwartalnik Historyczny” 1973/3.

${ }^{30}$ Przejął niemal w całości postanowienia Sudiebnika z 1497 r., choć był od niego obszerniejszy. Obowiązywał przez prawie 100 lat, pełniąc funkcję źródła prawa, które umacniało rosyjskie samodzierżawie. Por. M.Szczaniecki, Powszechna historia państwa i prawa, Warszawa 2003, s. 206.

31 Według Aleksandra Dugina „modernizacja, jednak bez westernizacji, a prowadząca także do centralizacji władzy" były głównymi celami Iwana IV, które wyłoniły się w wyniku prowadzonej wojny inflanckiej. Por. P.Heizer, Neoopricznina - Aleksander Dugini Eurazjatycki Zwiazek Młodzieży, „Przegląd Rusycystyczny” 140/4 (2012), s. 79-80.

${ }^{32}$ Zdaniem amerykańskiego historyka Marca Raeva Wielkie Księstwo Moskiewskie, a później Rosja, w okresie rządów Iwana IV prowadziło wzorem starożytnego Rzymu „obronny imperializm”. Każde zdobyte przez Rosję na różny sposób terytorium miało swoich sąsiadów, którzy stawali się wkrótce zbyt niebezpieczni, aby pozostawić ich w spokoju. W związku z tym jeden podbój szybko rodził następny, powodując coraz większy rozwój terytorium Rosji. Według tego autora istnienie Rosji nigdy nie było zagrożone w XV-XVI w. 
IV wzmocniło pozycję Rosji na arenie międzynarodowej. Należały na pewno do nich: koronacja na cara, przyłączenie Kazania i Astrachania, kolonizacja Syberii, uzyskanie supremacji nad Ordą Nogajska, początkowe sukcesy w wojnie inflanckiej (zdobycie Narwy i prawie całych Inflant, zdobycie Połocka), uczestnictwo w grze o elekcyjny tron polski w 1572 r., ustanowienie kontaktów handlowych z Anglią i Rzeszą niemiecką oraz Habsburgami, zlikwidowanie zagrożenia na wschodnich granicach państwa, uczynienie z Rosji pośrednika w handlu z Azją Wschodnią, reformy wewnętrzne w państwie ${ }^{33}$. Drugi okres w rządach Iwana IV, od roku 1565 do śmierci w 1584 r., charakteryzuję się względnym obniżeniem pozycji Rosji na zewnętrz i kłopotami wewnętrznymi, co było skutkiem wprowadzenia opriczniny.

Do porażek tego okresu możnazaliczyć: klęski w wojnie inflanckiej łącznie $\mathrm{z}$ traktatami w Jamie Zapolskim i nad rzeką Plussą, nieudane starania ouzyskaniedostępu do Bałtyk ani do Morza Czarnego, niepodjęcie wyprawy na chanat krymski, wyalienowanie na arenie międzynarodowe, opricznina, spadek ludności państwa i jego dochodów, zaprzestanie reform w duchu kompromisu między carem a stanami.

Mimo tych porażek Iwan IV dowiódł, że Rosja jest siłą, z którą ówcześnie należało się liczyć w Europie. Kraj pozostawiony następcy, carowi Fiodorowi (1584-1598), był rozleglejszy niż ten, który obejmował Iwan IV. Zapoczątkowanie kolonizacji Syberii stworzyło z Rosji eurazjatyckie imperium i w dużym stopniu zapoczątkowało rolę Rosji w świecie jako mocarstwa ${ }^{34}$. Charakter Iwana IV miał duży wpływ na jego działania, jednak nie można nim wszystkiego tłumaczyć. Dużą rolę odgrywały ideologia i względy geopolityczne. Ekspansja na Wschód i kolonizacja Syberii była thumaczona tym, że car został spadkobiercą chanów Złotej Ordy. Legitymizowano to także jako odzyskiwanie dziedzictwa wielkich książąt kijowskich oraz krucjatę przeciw islamowi i niewiernym. Również wojny o dostęp do Bałtyku i przeciw państwu polsko-litewskiemu legitymizowano jako kampanie o odzyskanie ziem należących do Ruryka czy „zbieranie ziem ruskich". Występująca w czasie panowania Iwana IV motywacja dynastyczna i religijna podbojów była silniejsza nawet od względów związanych z ponownym zjednoczeniem narodowym lub etnicznym.

Oprócz wspomnianych czynników wielką rolę odgrywały idee wywodzące się z Bizancjum. Za czasów Iwana IV zatriumfowała idea o więzi Bizancjum z terenami Rosji, przez pośrednictwo Rusi Kijowskiej sprzed najazdu mongolskiego (rola Włodzimierza Monomacha w XI w.). Była ona nawet silniejsza niż koncepcja przeniesienia po upadku Konstantynopola imperialnego statusu dawnego Bizancjum „Moskwa jako trzeci Rzym”.

Autorzy artykułu uważają, że Iwan IV Groźny nie zrealizował do końca swoich marzeń o kontynuacji dziedzictwa Rusi Kijowskiej i uzyskania tytułucara „całej Rusi”. Mimo to można powiedzieć, że na jego panowanie składało sięwiele sukcesów i takich

\footnotetext{
${ }^{33} \mathrm{~W}$ momencie obejmowania tronu Iwan III Srogi w 1462 r. odziedziczył terytorium 430 tys. $\mathrm{km}^{2}$, w chwili śmierci Wasyla III w 1533 r. terytorium Wielkiego Księstwa Moskiewskiego obejmowało już 2,8 $\mathrm{mln} \mathrm{km}^{2}$, a w końcu XVI w. obszar Rosji podwoił się do 5,4 $\mathrm{mln} \mathrm{km}^{2}$. Zob. szerzejR. Pipes, op. cit., s. 81-85.

${ }^{34}$ Według Iwony Massaki głównymi „ośrodkami krystalizacyjnymi światopoglądu eurazjatyckiego są: idea imperium, koncepcja kultury eurazjatyckiej, niechętny stosunek do kultury zachodniej”. Zob. szerzejI. Massaka, Eurazjatyzm. Z dziejów rosyjskiego misjonizmu, Wrocław 2001, s. 10-11.
} 
samych porażek. A najważniejsze idee Iwana IV, do dziś bardzo kontrowersyjnego cara, będą realizowane przez jego następców ${ }^{35}$.

\section{LITERATURA}

[1] Acton E., Rosja dziedzictwo caratu i władzy radzieckiej, Warszawa 2013.

[2] Aleksiejewa W., Zieleniew J. I., Jakunin W.I., Gieopolitika w Rossiji. MieżduWostokom $i$ Zapadom. Koniec XVIII - naczało XX w., SanktPetersburg 2001.

[3] Andrusiewicz A., Iwan Groźny, Warszawa 2006.

[4] Bäcker R., Międzywojenny eurazjatyzm. Od intelektualnej kontrakulturacji do totalitaryzmu?, Łódź 2000.

[5] Bazylow L., Wieczorkiewicz P., Historia Rosji, Wrocław 2005.

[6] Besancon A., Święta Ruś, Warszawa 2012.

[7] Billington J.H.,Ikonaitopór. Historia kultury rosyjskiej,Kraków 2008.

[8] Bogucka M., Zboże rosyjskie na rynku amsterdamskim $w$ pierwszej połowie XVII wieku, „Przegląd Historyczny”1962/4.

[9] Bojko K., Stosunki dyplomatyczne Moskwy z Europa Zachodnia w czasach Iwana III, Kraków 2010.

[10] Braudel F., Kultura materialna, gospodarka i kapitalizm XV-XVIII wiek. Gry wymiany, t.III, Warszawa 1992.

[11] Braudel F., Morze Śródziemne i świat śródziemnomorski w epoce Filipa II, t. 1, Warszawa 2004.

[12] Carrèred'Encausse H., Eurazjatyckie imperium. Historia Imperium Rosyjskiego od 1552 r. do dzisiaj, Kęty 2014.

[13] Chodakowski N.I., TretijRim, Moskwa 2002.

[14] Chojnicka K., Idee towarzyszace procesowi uzyskiwania przez Moskwe dominacji na ziemiach ruskich $w$ XV, XVI wieku, [w:] Oblicza Wschodu w kulturze polskiej, red. G. Kotlarski, M. Figura,Poznań 1999.

[15] Chojnicka K., Narodziny rosyjskiej doktryny państwowej. ZoePaleolog między Bizancjum, Rzymem a Moskwą, Kraków 2001.

[16] Czy Putin jest awatarem? - rozmowa z Aleksandrem Duginem, „Fronda” 2001/23-24.

[17] Fennell J.L.I., The Correspondence between Prince A. M. Kurbsky and Tsar Ivan IV of Russia, Cambridge 1955.

[18] Floria B.N., Magnateria litewska a Rosja w czasie drugiego bezkrólewia, „Odrodzenie i reformacja”1977/XXII.

[19] Floria B.N., Russko-polskijeotnoszenii i politiczeskojerazwitjeWostocznojJewropywowtoroj połowinie XVI - naczale XVII w., Moskwa 1978

${ }^{35}$ Zob. szerzej Łapiński Z., Pośmiertny żywot Iwana Groźnego, „Tygodnik Powszechny” 1987/42. Aleksander Duginzauważa: „Historię jako wznoszenie się od Rusi Kijowskiej do Rusi Moskiewskiej, którego szczytem był okres Iwana Groźnego. Potem nastąpiło opadanie do okresu petersburskiego ze zdegenerowanymi, zorientowanymi na Zachód rządami dynastii Romanowów. Rewolucja październikowa w roku 1917 wraz z przeniesieniem stolicy z Petersburga do Moskwy w wielu aspektach stanowiła powrót do idei Rusi Moskiewskiej”. Por. Czy Putin jest awatarem? rozmowa z Aleksandrem Duginem, „Fronda” 2001/23-24, s. 159. 
[20] Floria B.N., IwanGroznyj, Moskwa 1999.

[21] Franklin S., Sheppard J., The Emergence of Rus, 750-1200, London 1996.

[22] Gerson A.J., Vaughn E.V., Studies in the history of English commerce in the Tudor period, I:The organization and early history of the Muscovy company, II:English trading expeditions into Asia under the authority of the Muscovy company (1557-1581), New York 1912.

[23] Gołąbek P., Lew GumilowiAleksanderDugin. O dwóch obliczach eurazjatyzmu w Rosji po 1991 roku, Kraków 2012.

[24] Gumilow L., Od Rusi do Rosji, Warszawa 2004.

[25] HalperinCh.J., Russia and Golden Horde: the Mongol Impact on Medieval Russian History, London 1987.

[26] Heizer P., Neoopricznina - Aleksander Dugin i Eurazjatycki Związek Młodzieży, „Przegląd Rusycystyczny”140/4 (2012).

[27] Heller M., Historia Imperium Rosyjskiego, Warszawa 2009.

[28] Historia dyplomacji polskiej, t. I:Połowa X w. - 1572, red. M. Biskup, Warszawa 1982.

[29] Kaługin W., Car Iwan Groznyj i kniaź Andriej Kurbskij: Stili myszlenija i tworczestwa, [w:] Pisarz i władza. Od Awwakuma do Solżenicyna, red. B. Mucha,Łódź 1994.

[30] Kennedy P., Mocarstwa świata. Narodziny, rozkwit, upadek, Warszawa 1994.

[31] Khodarkovsky M., Four Degrees of Separation: Constructing Non-Christian Identities in Muscovy, [w:] Culture an Identity in Muscovy, 1359-1584, red. A.M. Kleimola, G.D. Lenhoff,Moskwa 1994.

[32] Khodarkovsky M., Na granicach Rosji. Budowanie imperium na stepie 1500-1800, Warszawa 2009.

[33] Kłoczowski J., Młodsza Europa, Warszawa 2003.

[34] Kobrin W., Iwan Groznyj, Moskwa 1989.

[35] Koneczny F., Cywilizacja bizantyńska, Londyn 1973.

[36] Krasowski K., Lesiński B., Sikorska-Dzięgielewska K., Walachowicz J., Powszechna historia państwa i prawa, Poznań 1993.

[37] LeDonne J. P., The Russian Empire and the World. The Geopolitics of Expansion and Containment, Oxford 1997.

[38] Łapiński Z., Pośmiertny żywot Iwana Groźnego, „Tygodnik Powszechny” 1987/42.

[39] Madejski D., Pocatunek mongolskiego księcia. Eurazjatyzm Rosji w myśli Aleksandra Dugina,cz. I, 2011, http://www.konserwatyzm.pl/artykul/3266/pocalunek-mongolskiego-ksieciaeurazjatyzm-rosji-w-mysli-ale.

[40] Madriaga I. de, Ivan the Terrible, New Haven 2005.

[41] Malleson G.B., The Decisive Battles of India from 1746 to 1819, London 1885.

[42] Małowist M., Wschód a Zachód Europy XIII-XVI wieku, Warszawa 2006.

[43] Marciniak W., Imperium i państwo: historia pojęć w kontekście dziejów Rosji, [w:] Rosja i Europa Wschodnia: „imperiologia stosowana”,red. A. Nowak, Kraków 2006.

[44] Martin J., Medieval Russia, 980-1584, Cambridge 1995.

[45] Massaka I., Eurazjatyzm. Z dziejów rosyjskiego misjonizmu, Wrocław 2001. 
[46] Michajłow W. A., Gieopolitika. Ucziebnik, Moskwa 2010.

[47] Morris J., Dlaczego Zachód rządzi - na razie, Poznań 2015.

[48] Natanson-Leski J., Granica moskiewska w epoce jagiellońskiej, Oświęcim 2014.

[49] Nowak A., Putin. Źródła imperialnej agresji, Warszawa 2014.

[50] Nye J., Soft Power. Jak osiagnać sukces $w$ polityce światowej, Warszawa 2007.

[51] Ostrowski D, Muscovy and the Mongols: Cross-Cultural Influences on the Steppe Frontier, 1304-1589, Cambridge 1998.

[52] Pain E.A., Mieżduimperiej a nacyiej. Modernistskij projekt $i$ jgotradicyonalistkajaaltiernativa $w$ nacyonalnojpolitikieRossii. FondLibieralnajamisija, Moskwa 2003.

[53] Paradowski R., Eurazjatyckie imperium Rosji. Studium Idei, Toruń 2001.

[54] Pawłow A., Perrie M., Iwan Groźny. Car i tyran, Warszawa 2008.

[55] Pelenski J., Russia and Kazan. Conquest and Imperial Ideology (1438-1560s), The Hague 1974.

[56] Pipes R., Rosja carów, Warszawa 2012.

[57] Płatonow S.F., Ivan the Terrible, Gulf Breeze 1974.

[58] Poe M., Izobrietienije koncepciji „Moskwa - trietij Rim”, „Ab Imperio” 2000/2.

[59] Riasanovsky N.V., Steinberg M.D.,Historia Rosji, Kraków 2009.

[60] Rojek P., Przekleństwo imperium. Źródła rosyjskiego zachowania, Kraków 2014.

[61] Rowland D., Moscow - The Third Rome or the New Israel?, „Russian Review" 1996.

[62] Salimow I., PoliticzieskajageomorfologijaRossiji, [w:] Impierijaprostranstwa. Chriestomatija po gieopolitikie i gieokulturieRossiji, red.D.N. Zamiatin,A.N. Zamiatin, Moskwa 2003.

[63] Serczyk W.A., Iwan Groźny, Wrocław-Warszawa-Kraków-Gdańsk 1977.

[64] Serczyk W.A., Radziecka dyskusja o absolutyzmie $w$ Rosji, „Kwartalnik Historyczny" 1973/3.

[65] Shaw S., Historia Imperium Osmańskiego $i$ Republiki Tureckiej,t.1:1280-1808, Warszawa 2012.

[66] Skrynnikow R.G., Ivan the Terrible, Gulf Breeze 1981.

[67] Skrynnikow R.G., TragiedijaNowgoroda, Moskwa 1994.

[68] Soloviev A.V., Holy Russia. The History of a Religious - Social Idea, Gravenhage 1959.

[69] Stevens C.B., Rosyjskie wojny 1460-1730. Narodziny mocarstwa, Warszawa 2003.

[70] Szczaniecki M., Powszechna historia państwa i prawa, Warszawa 2003.

[71] Tarczyński A., Podbój imperiów Inków i Azteków, Warszawa 2009.

[72] Topolski J., Narodziny kapitalizmu w Europie w XIV-XVII w., Poznań 2003.

[73] Urban W., Nowożytni najemnicy, Warszawa 2008.

[74] Uspienski B., Car i patriarcha. Charyzmat władzy w Rosji. Bizantyjski model $i$ jego nowe rosyjskie ujęcie, Katowice 1999.

[75] Uspienski B., Religia i semiotyka, wybrał, przeł.i przedmową opatrzył B. Żyłko, Gdańsk 2001. 
[76] Willan T.S., The Early History of the Russia Company, 1553-1603, Manchester 1956.

[77] Wipper P.Y., Ivan Grozny, Moskwa 1994.

[78] Wójcik Z., Dzieje Rosji1533-1801, Warszawa 1971.

[79] Wójcik Z., Wokół epoki Iwana Groźnego, „Kwartalnik Historyczny” 1975/2.

[80] Zajączkowski W., Rosja i narody. Ósmy kontynent. Szkic dziejów Eurazji, Warszawa 2009.

[81] Zakrzewski W., Stosunki Stolicy Apostolskiej z Iwanem Groźnym i wielkim księciem moskiewskim, „Przegląd Polski”1872-1873/I-IV.

\section{THE ASSUMPTIONS OF GEOPOLITICS AND IT IMPLEMENTATION IN RUSSIA IVAN IV THE TERRIBLE IN THE YEARS 1547-1584. PART II}

The article presents the main assumptions geopolitical reign of the Russian Tsar Ivan IV the Terrible and methods of their implementation. The expansion of Russia at that time has focused largely on the same geography, but to translate this into correct actions in time and space belonged to Ivan IV. Even during the Great Duchy of Moscow there were marked major geo-strategic ambitions. These included: 1 . Ensuring safety from the eastern borders of the state and directing the expansion against states that are the heirs of the Mongols. 2. Gaining access to the Baltic Sea and borders moved west, to unite the lands belonging to the centuries to Kievan Rus. This "gathering of the Russian lands" had also connect Orthodox believers under one rule of the Russian Orthodox Church. 3. Development of appropriate ideologies to justify policy issues. At this time, there is the theory of Moscow as the "Third Rome", designed after the fall of Constantinople confirmed Moscow's authority over all Orthodox peoples, and in the future being a factor justifying claims to Russian territories of the former Byzantine Empire. Ivan IV the Terrible as a result of actions taken to become one of the first rulers of Russia, who with considerable success realized these geopolitical assumptions, while also referring successes. He was also the first ruler who created in his actions the concept of "Eurasian Russia". The article consists of two parts discussing implementation and successes and failures of Ivan IV the Terrible at the three main lines of its policy. Goals it has set itself the car have not been fully realized by him, but he played the role of a universal for future rulers of Russia, who likes realizing his political testament aspired to similar objectives in foreign policy. The judgment of the activities of Tsar Ivan IV of Russia to this day it is not clear, from adoration to the hatred.

Keywords: Ivan IV the Terrible, geopolitics, Russia in the sixteenth century, The Russian Wars.

DOI:10.7862/rz.2016.hss.33

Przesłano do redakcji: wrzesień 2015

Przyjęto do druku: styczeń 2016 